groups and adjust for clustering are likely to strengthen the findings presented here.

\section{Conclusions}

As expectations of continuing growth have evaporated in industrialised countries with the advent of the global economy, downsizing has become an increasingly important trend. This study indicates that downsizing may lead to elevated absence rates and increase cardiovascular mortality among people who remain employees. Policy makers, employers, and occupational health professionals should recognise that downsizing may pose a severe risk to health.

Contributors: See bmj.com

Funding: This study was supported by the Academy of Finland (projects 77560, 104891, and 105195), the Finnish Work Environment Foundation (project 101190), and the participating towns. MK also works at the Department of Psychology, University of Helsinki, Finland. JEF is supported by the Medical Research Council (grant number 47413).

Competing interests: None declared.

Ethical approval: The ethics committee of the Finnish Institute of Occupational Health approved the study.

1 Vahtera J, Kivimäki M, Pentti J. Effect of organisational downsizing on health of employees. Lancet 1997;350:1124-8.

2 Kivimäki M, Vahtera J, Pentti J, Thomson L, Griffiths A, Cox T. Downsizing, changes in work, and self-rated health of employees: a 7-year 3-wave panel study. Anxiety, Stress and Coping 2001;14:59-73.

3 Kivimäki M, Vahtera J, Pentti J, Ferrie JE. Factors underlying the effect of organisational downsizing on health of employees: longitudinal cohort organisational downsizing
4 Quinlan M, Mayhew C, Bohle P. The global expansion of precarious employment, work disorganization, and consequences for occupational health: a review of recent research. Int J Health Serv 2001;31:335-414.

5 Theorell T, Oxenstierna G, Ferrie J, Hagberg J, Alfredsson L. Downsizing of staff is associated with lowered medically certified sick leave in female employees. Occup Environ Med 2003;60:e9.

6 Aronsson G, Gustafsson K, Dallner M. Sick but yet at work: an empirical study of sickness presenteeism. I Epidemiol Community Health 2000;54:502-9.

7 Virtanen M, Kivimäki M, Elovainio M, Vahtera J, Ferrie JE. From insecure to secure employment: changes in work, health, health related behaviours, and sickness absence. Occup Environ Med 2003;60:948-53.

8 Classification of occupations: handbook no 14. Helsinki: Statistics Finland, 1987.

9 North F, Syme SL, Feeney A, Head J, Shipley MJ, Marmot MG. Explaining socioeconomic differences in sickness absence: the Whitehall II study. BMJ 1993;306:361-6.

10 Melchior M, Niedhammer I, Berkman LF Goldberg M. Do psychosocial work factors and social relations exert independent effects on sickness absence? A six year prospective study of the GAZEL cohort. J Epidemiol Community Health 2003;57:285-93.

11 Kivimäki M, Leino-Arjas P, Luukkonen R, Riihimäki H, Vahtera J, Kirjonen J. Work stress and risk of cardiovascular mortality: prospective cohort study of industrial employees. BMJ 2002;325:857-61.

12 Everson SA, Lynch JW, Chesney MA, Kaplan GA, Goldberg DE, Shade SB, et al. Interaction of workplace demands and cardiovascular reactivity in progression of carotid atherosclerosis: population based study. BMJ 1997:314:553-8.

13 McLeod J, Davey Smith G, Heslop P, Metcalfe C, Carroll D, Hart C. Psychological stress and cardiovascular disease: empirical demonstration of bias in a prospective observational study of Scottish men. $B M$ J 2002;324:1247-51.

14 Lynch JW, Kaplan GA, Pamuk ER, Cohen RD, Heck KE, Balfour JL, et al. Income inequality and mortality in metropolitan areas of the United States. Am J Public Health 1998:88:1074-80.

(Accepted 27 November 2003)

doi 10.1136/bmj.37972.496262.0D

\title{
Use of lithium and the risk of injurious motor vehicle crash in elderly adults: case-control study nested within a cohort
}

\author{
Mahyar Etminan, Brenda Hemmelgarn, J A C Delaney, Samy Suissa
}

Division of Clinical Epidemiology, Royal Victoria Hospital, McGill University Health Centre, 687 Pine Ave, West Montreal, Quebec, Canada

H3A 1A1

Mahyar Etminan pharmacoepidemiology fellow

J A C Delaney doctoral student Samy Suissa professor and director

\section{Departments of} Medicine and Community Health Sciences, University of Calgary, Calgary, Alberta, Canada

Brenda

Hemmelgarn assistant professor Correspondence to: Samy Suissa Samy.suissa@ clinepi.mcgill.ca

BMJ 2004;328:558-9
Since its introduction in the 1960s lithium has been an effective agent for stabilising mood in the treatment of bipolar disorder. However, its use has been linked to impaired memory and slow reaction times. ${ }^{1}$ Car crashes resulting from drug use are becoming a major public health hazard among elderly people. ${ }^{2}$ We assessed the association between elderly people's use of lithium and their involvement in motor vehicle crashes. We also assessed another common mood stabiliser, carbamazepine, which has a different mechanism of action to lithium.

\section{Subjects, methods, and results}

We used a case-control approach on data from a cohort that has been described previously. ${ }^{3}$ Briefly, we used the Universal Quebec Automobile Insurance Agency to identify all 224734 drivers aged between 67 and 84 years in the province of Quebec at 1 June 1990 and followed them up to 31 May 1993. To be included in the cohort subjects needed to have a valid driver's licence and to have lived in Quebec for at least two years before 1 June 1990. Cohort subjects were followed up until they reached the age of 85 or emigrated from Quebec or until 31 May 1993, whichever was the earliest. We defined the study outcome as subjects' involvement, as drivers, in a motor vehicle crash in which at least one person sustained a physical injury. Cases were subjects who had any such crash during the follow up period, and the date of their first crash was taken as the index date. Controls were a $6 \%$ random sample of the cohort, and their index dates were randomly selected during the follow up.

Exclusion criteria were the same as in the previous study. ${ }^{3}$ We used data from the Quebec Health Insurance Agency to identify subjects' use of prescription drugs and other covariate information. The database on prescription drugs includes information on all outpatient prescriptions of drugs dispensed to people aged 65 years or older. The accuracy and validity of these data have been shown to be high. ${ }^{4}$

We used logistic regression to compute the odds ratio as an estimate of the rate ratio of an injurious motor vehicle crash associated with use of lithium or carbamazepine. We defined exposure to the drugs as any prescription in the year before the index date and current use as a prescription dispensed in the 60 days before the index date. We adjusted for age, sex, place of residence (urban or rural), previous involvement in an

This article was posted on bmi.com on 19 January 2004: http://bmi.com cgi/doi/10.1136/bmj.38002.514838.94 
injurious motor vehicle crash, chronic disease score, and exposure to central nervous system drugs in the 60 days before the crash.

A total of 5579 people in the cohort had had an injurious motor vehicle crash during the follow up period. A random sample of 13300 control subjects was drawn from the cohort. Current use of lithium was higher among subjects who had been involved in an injurious motor vehicle crash than among control subjects (rate ratio 2.08 (95\% confidence interval 1.11 to 3.90) (table 1). Current use of carbamazepine was not associated with having had an injurious motor vehicle crash (rate ratio 0.83 (0.48 to 1.44$)$ ).

\section{Comment}

Elderly people who use lithium may increase by twofold the risk of being involved in an injurious motor vehicle crash while driving. We had no information on diagnoses of bipolar disorder in this group (including severity of disease). Our sample size was too small to allow stratification by number of drugs used. There may, therefore, have been a small possibility in our study of confounding by indication due to disease severity.

A recent retrospective cohort study found lithium to be more efficacious than valproate semisodium (divalproex sodium) in preventing suicides. ${ }^{5}$ That finding may prompt clinicians to favour lithium over other mood stabilising agents. Patients who are prescribed lithium must be told about the increased risk of motor vehicle crashes.

Contributors: ME, JACD, BH, and SS designed and performed the study.JACD did the statistical analysis. SS is the guarantor. Funding: Canadian Institute of Health Research and the Fonds de la Recherche en Santé du Québec.

Competing interests: None declared.
Rate ratios for having been involved as a driver in an injurious motor vehicle crash (cases), according to drug use

\begin{tabular}{|c|c|c|c|c|}
\hline \multirow[b]{2}{*}{ Drug use } & \multirow{2}{*}{$\begin{array}{l}\text { No of cases } \\
(n=5579)\end{array}$} & \multirow{2}{*}{$\begin{array}{c}\text { No of controls } \\
(n=13300)\end{array}$} & \multicolumn{2}{|c|}{ Rate ratio } \\
\hline & & & Crude & Adjusted $^{\star}(95 \% \mathrm{Cl})$ \\
\hline \multicolumn{5}{|l|}{ Lithium } \\
\hline $\begin{array}{l}\text { Any use in the year before } \\
\text { index date†: }\end{array}$ & 20 & 27 & 1.77 & 1.80 (1.00 to 3.24$)$ \\
\hline 1-4 prescriptions & 2 & 8 & 0.60 & $0.71(0.15$ to 3.45$)$ \\
\hline$\geq 5$ prescriptions & 18 & 19 & 2.26 & 2.18 (1.14 to 4.19$)$ \\
\hline $\begin{array}{l}\text { Current use (within } 60 \text { days } \\
\text { before index date } \dagger \text { ) }\end{array}$ & 19 & 22 & 2.06 & 2.08 (1.11 to 3.90$)$ \\
\hline \multicolumn{5}{|l|}{ Carbamazepine } \\
\hline $\begin{array}{l}\text { Any use in the year before } \\
\text { index date†: }\end{array}$ & 36 & 79 & 1.09 & $1.04(0.70$ to 1.54$)$ \\
\hline 1-4 prescriptions & 18 & 41 & 1.05 & 1.02 (0.58 to 1.79$)$ \\
\hline$\geq 5$ prescriptions & 18 & 38 & 1.13 & 1.05 (0.58 to 1.85$)$ \\
\hline $\begin{array}{l}\text { Current use (within } 60 \text { days } \\
\text { before index date } \dagger \text { ) }\end{array}$ & 18 & 48 & 0.90 & 0.83 (0.48 to 1.44$)$ \\
\hline
\end{tabular}

*Adjusted for age, sex, residence in the country, previous involvement in an injurious motor vehicle crash, chronic disease score, and exposure in the 60 days before the index date to antidepressants, anti-epileptics, benzodiazepines, antipsychotics, antimigraine drugs, muscle relaxants, or narcotic analgesics. †The date of each driver's first crash in the follow up period (for cases) or a random date (for controls).

Ethical approval: Ethics committee of the Department of Epidemiology and Biostatistics, McGill University, Montreal.

1 Honig A, Arts BM, Ponds RW, Riedel WJ. Lithium induced cognitive sideeffects in bipolar disorder: a qualitative analysis and implications for daily practice. Int Clin Psychopharmacol 1999;14:167-71.

2 Verster JC, de Weert AM, Bijtjes SI, Aarab M, van Oosterwijck AW, Eijken EJ, et al. Driving ability after acute and sub-chronic administration of levocetirizine and diphenhydramine: a randomized, double-blind, placebocontrolled trial. Psychopharmacology) (Berl) 2003:169:84-90.

3 Hemmelgarn B, Suissa S, Huang A, Boivin JF, Pinard G. Benzodiazepine use and the risk of motor vehicle crash in the elderly. JAMA 1997;278:
und 27-31.

4 Tamblyn R, Lavoie G, Petrella L, Monette J. The use of prescription claims databases in pharmacoepidemiological research: the accuracy and comprehensiveness of the prescription claims database in Quebec.J Clin Epidemiol 1995;48:999-1009.

5 Goodwin FK, Fireman B, Simon GE, Hunkeler EM, Lee J, Revicki D. Suicide risk in bipolar disorder during treatment with lithium and divalproex. JAMA 2003;290:1467-73.

(Accepted 12 November 2003)

doi $10.1136 /$ bmj.38002.514838.94

\section{A memorable patient}

\section{Aggie}

I will call her Agatha Radcliffe, though that is not her real name. Nor was she my patient. I was on rota duty on a freezing, wintry Saturday night some time in the 1950s. The day had been long and arduous, and, at about 11 o'clock, having just got home from another visit, I received an urgent call to visit a Miss Radcliffe, who was having an asthma attack.

It didn't take long to get to her house. She was sitting up in bed, her head between her hands with her elbows resting on her knees, gasping. No stethoscope was needed to hear the sibilant rhonchi. She was in her 70s, a frail spinster with white hair, weighing no more than eight stone, and with rather fine chiselled features. She had obviously been very beautiful when she was young. I wanted to give her an injection of aminophylline but had none with me, so I told her that I would get some from my surgery, which was less than a mile away, and she seemed to be satisfied when I assured her that I would be back soon.

As I got into my car the lightning flash of recognition pierced my weary brain. Agatha Radcliffe! Yes, old Aggie Radcliffe, fancy that now. Agatha Radcliffe, that was the name of one of my teachers way back in my elementary (now known as primary) school. We all called her Aggie, and all the boys, including myself, were in love with her. What a shame she never married, but in those days female teachers were obliged to retire if they chose to marry. I couldn't wait to get back to reveal my identity to her.
As I slowly injected the aminophylline, I said, "You don't know me do you?"

"You're Hyman Davies," came the prompt reply.

"Did you recognise me when I first came into the house?"

"Of course I did."

"Then why didn't you tell me?"

"I was waiting to see if you would recognise me," she answered.

"And what would you have done if I hadn't?"

"I would have let you go on your way."

I hadn't seen her since I left that school, more than 20 years ago, and she not only remembered me but also remembered the names of my two older brothers, who had also been her pupils, and the names of almost every lad in my class. The injection worked, and soon she was able to talk without difficulty. We spent a long long time reminiscing; the school had included among its past pupils some high fliers, including a violin virtuoso, a fellow of the Royal Society, an eminent civil servant, various legal luminaries, and several common or garden doctors and dentists. And she reminded me of some whom I had totally forgotten.

I came away with that warm glow of satisfaction, of having done a good job for a fine lady, albeit a tiny reward for what she had done for me.

Hyman Davies retired general practitioner, Prestwich, Manchester 